
using green manure in pre-cultivation and organic top dressing fertilization. Horticultura Brasileira 36: 515-520. DOI - http://dx.doi.org/10.1590/S0102053620180415

\title{
Organic cabbage growth using green manure in pre-cultivation and organic top dressing fertilization
}

\author{
Ana Amélia S Cordeiro ${ }^{1}$; Marinete B Rodrigues²; Murilo Gonçalves Júnior²; José Antônio A Espíndola ${ }^{3}$; Ednaldo da \\ S Araújo ${ }^{3}$; José Guilherme M Guerra ${ }^{3}$
}

${ }^{1}$ Instituto Federal do Norte de Minas Gerais (IFNMG), Arinos-MG, Brazil; ana.cordeiro@ifnmg.edu.br; ${ }^{2}$ Universidade Federal Rural do Rio de Janeiro (UFRRJ), Seropédica-RJ, Brazil;. marinete.rodrigues@yahoo.com.br; murilojunior3@yahoo.com.br; ${ }^{3}$ Embrapa Agrobiologia, Seropédica-RJ, Brazil; jose.espindola@embrapa.br; ednaldo.araujo@embrapa.br; guilherme.guerra@embrapa.br

\begin{abstract}
The experiment was conducted in (Integrated Agroecological Production System in Seropedica-RJ) Sistema Integrado de Produção Agroecológica (SIPA), Seropédica-RJ, to evaluate the effect of two maize populations in relation to baby corn productivity and shoot mass, to determine the contribution of pre-cultivated maize, green velvet and organic topdressing fertilization in the agronomic performance of cabbage (Brassica oleracea var. capitata). The experimental design consisted of randomized blocks with three treatments (maize population of 100,000 and 200,000 plants ha ${ }^{-1}$ and green velvet at 100,000 plants ha ${ }^{-1}$ ) and eight replicates. After that, cabbage was transplanted in the straw of these species, adopting a randomized block design allocated in split plots, totalizing six treatments, being three pre-cultivation practices and two organic topdressing fertilization doses (with or without $50 \mathrm{~g}$ fermented organic compost per planting hole). Considering "baby corn" productivity, no differences were observed compared to maize populations, with an average productivity of $822.5 \mathrm{~kg} \mathrm{ha}^{-1}$. Green velvet pre-cultivation obtained the highest shoot dry mass $\left(8.4 \mathrm{th}^{-1}\right)$. Cabbage crop was improved by green velvet pre-cultivation, reaching $60.7 \mathrm{t} \mathrm{ha}^{-1}$ and organic topdressing fertilization, reaching $60.4 \mathrm{t} \mathrm{ha}^{-1}$; however, in the presence of green velvet straw, topdressing fertilization did not promote additional yield benefit of this crop. Thus, we noticed that green manure using green velvet increased cabbage productivity, submitted to organic management, when compared to maize precultivation, making it able to replace organic topdressing fertilization.
\end{abstract}

Keywords: Brassica oleracea var. capitata, agroecology, minimum tillage, baby corn, corn stigmas, velvet green.

\section{RESUMO}

Cultivo orgânico de repolho com adubação verde em précultivo e adubação orgânica em cobertura

O experimento foi conduzido na área do Sistema Integrado de Produção Agroecológica (SIPA), Seropédica-RJ, objetivando avaliar o efeito de duas populações de milho quanto à produtividade de minimilho e de massa de parte aérea, determinar a contribuição dos pré-cultivos de milho, da mucuna verde e da adubação orgânica de cobertura, no desempenho agronômico do repolho. O delineamento adotado foi constituído de blocos casualizados, com três tratamentos (milho nas densidades de 100.000 e 200.000 plantas ha $^{-1}$ e mucuna verde na densidade de 100.000 plantas ha ${ }^{-1}$ ) e oito repetições. $\mathrm{Na}$ sucessão, realizou-se o transplantio do repolho na palhada destas espécies, adotando-se o delineamento de blocos casualizados distribuídos em parcelas subdivididas, totalizando seis tratamentos, sendo três pré-cultivos e duas doses de adubação orgânica de cobertura (ausência e presença de $50 \mathrm{~g}$ de composto orgânico fermentado por cova). Considerando a produtividade de "minimilho", não foram observadas diferenças em decorrência das populações de milho, com produtividade média de $822,5 \mathrm{~kg} \mathrm{ha}^{-1}$. A maior produtividade de massa seca de parte aérea dos pré-cultivos foi obtida com mucuna verde $\left(8,4\right.$ tha $\left.^{-1}\right)$. A cultura do repolho foi beneficiada pelo pré-cultivo com a mucuna verde, alcançando $60,7 \mathrm{t} \mathrm{ha}^{-1}$ e pela adubação orgânica de cobertura, alcançando $60,4 \mathrm{t} \mathrm{ha}^{-1}$, todavia, na presença da palhada de mucuna verde, a adubação de cobertura não promoveu benefício adicional no rendimento desta hortaliça. Desta forma, evidenciou-se que a adubação verde utilizando a leguminosa mucuna verde proporciona aumento de produtividade de repolho, submetido ao manejo orgânico, quando comparado ao pré-cultivo de milho e é capaz de substituir a adubação orgânica de cobertura.

Palavras-chave: Brassica oleracea var. capitata, agroecologia, cultivo mínimo, minimilho, estigmas de milho, mucuna verde.

\section{Received on October 20, 2017; accepted on June 16, 2018}

\begin{abstract}
A stro strong appeal for sustainable agriculture has forced the search for new production systems, which include the replacement of synthetic fertilizers by organic ones. This practice promotes benefits to chemical, physical and
\end{abstract}

biological soil characteristics, resulting in higher productivities (Sediyama et al., 2014). The evolution of the production process led to the substitution of agricultural management practices, in which plant and animal farms were integrated, for specialized systems. That is the reason why local availability of organic matter for fertilization had been reduced.

Alternatively to manures, the use of fermented "Bokashi" compost, 
a fermented mixture of wheat bran and castor oil cake, inoculated with effective microorganisms (EM), has been widely used (Mata et al., 2016). The predominant fermentation process is lactic, however, acetic, alcoholic, propionic and butyric fermentation also occur (Siqueira \& Siqueira, 2013).

In tropical conditions, few scientific studies are related to the benefits of these fermented composts for plant mineral nutrition, though. Oliveira (2015) observed that the application of this compost resulted in an increase in number of leaves and fresh mass production of lettuce shoots (cv. Vera).

Another alternative to soil fertilization is the green manure. Silva et al. (2011b), studying succession of organic maize and kale cultivations under no-tillage system, verified that kale showed higher productivity, when intercropped with vegetables Crotalaria spectabilis and Mucuna deeringiana. Silva et al. (2011a) estimated that, in average, $67 \%$ of $\mathrm{N}$ in green velvet tissues is derived from the biological nitrogen fixation (BNF).

Using grass mulch has many advantages such as high capacity of mass production and nutrient cycling, mainly $\mathrm{K}$. Decomposition of the mulching with grass straw is lower than the mulching with vegetables (Silva, 2002). The decomposition rate of straw, in general, is inversely proportional to the $\mathrm{C} / \mathrm{N}$ ratio (Doneda, 2010), favoring the maintenance of mulching for a longer period of time.

Considering the maize shoot production, this species presents potential to be used as mulching. One alternative is producing straw and mini corn (baby corn) in situ. Baby corn is the female inflorescence harvested prior to fertilization (Barbosa, 2009), being processed as industrialized food, being source of additional cash income. Stigma (corn hair) is recommended by popular medicine to treat edema, cystitis, gout and kidney stones ( $\mathrm{Li}$ $\& \mathrm{Yu}, 2009)$. However, no results in relation to stigma production in maize fields in Brazil were found.

Many studies on management of Brassicacea in organic farming production have been carried out (Santos,
2009; Corrêa et al. 2014). This botanical family is a widely consumed food and has great socioeconomic importance (Filgueira, 2008) and also presents high nutrient extraction capacity (Silva et al., 2012). In conventional management, cabbage (Brassica oleracea var. capitata) is generally fertilized using high doses of soluble fertilizers (Aquino et al., 2005); however, in organic cultivation the green manure associated with organic fertilization provides good productivity levels for this vegetables (Pereira, 2007).

The aim of this study was to evaluate the effect of green manure, in precultivation with green velvet and corn in two population densities, associated with fermented organic compost "bokashi", on agronomic performance of cabbage submitted to organic cultivation.

\section{MATERIAL AND METHODS}

The experiment was installed at Sistema Integrado de Pesquisa em Produção Agroecológica (SIPA) "Fazendinha Agroecológica km 47", Seropédica, Rio de Janeiro State ( $22^{\circ} 45^{\prime} \mathrm{S}, 43^{\circ} 41^{\prime} \mathrm{W}, 33 \mathrm{~m}$ altitude).

The soil is classified as Argisol. Soil chemical analysis in the $0-20 \mathrm{~cm}$ layer, showed $\mathrm{pH}($ water $)=6.1 ; \mathrm{Al}^{+++}=0.0$ $\mathrm{cmol} \mathrm{dm}^{-3} ; \mathrm{Ca}^{++}=1.9 \mathrm{cmol} \mathrm{dm}^{-3} ; \mathrm{Mg}^{++}=$ $0.93 \mathrm{cmol}_{\mathrm{c}} \mathrm{dm}^{-3}$; available $\mathrm{P}=64 \mathrm{mg} \mathrm{dm}^{-3}$; $\mathrm{K}^{+}=50.0 \mathrm{mg} \mathrm{dm}^{-3}$; organic matter $=$ $1.41 \mathrm{~g} \mathrm{~kg}^{-1}$.

Cover crops were sown on February 22, 2011. Maize, cultivar Eldorado, was grown in a $1.0-\mathrm{m}$ spacing between furrows and 10 plants per linear meter $\left(100,000\right.$ plants ha $\left.\mathrm{a}^{-1}\right), 0.5 \mathrm{~m}$ between furrows and 10 plants per linear meter $\left(200,000\right.$ plants $\left.\mathrm{a}^{-1}\right)$. The green velvet (Mucuna pruriens cv. Utilis) was planted in $0.5-\mathrm{m}$ spacing between furrows and 5 plants per linear meter $\left(100,000\right.$ plants ha $\left.{ }^{-1}\right)$. The useful area consisted of $4 \mathrm{~m}^{2}$ of central green velvet plots, for corn $\left(100,000\right.$ plants $\left.\mathrm{ha}^{-1}\right) 2$ central rows measuring 2 meters long were delimited and for maize $(200,000$ plants ha $\left.{ }^{-1}\right) 4$ central rows measuring 2 meters long were delimited.

Baby corn ears were harvested between 56 and 75 days after sowing.
Those ears, measuring diameters from 0.8 to $1.8 \mathrm{~cm}$ (desired diameter) and with no deformations, were classified as marketable; the ones which were out of the desired diameter were classified as unmarketable (Pereira Filho \& Cruz, 2001) and mini corn with deformations were classified as unmarketable due to deformation. After determining fresh mass, subsamples of baby corn and stigmas were taken to be dried in forced air circulation at $65^{\circ} \mathrm{C}$ for 72 hours. Then, dry mass was quantified, ground and taken to Laboratório de Química Agrícola of Embrapa Agrobiologia to determine $\mathrm{N}, \mathrm{P}, \mathrm{K}, \mathrm{Ca}$ and $\mathrm{Mg}$ contents.

Cutting of corn and green velvet plants, in order to make straw mulch, was carried out during the green velvet flowering, at 144 days after sowing and kept on the soil. We quantified phytomass samples and took subsamples, then dry mass was quantified and macronutrients contents were analyzed, as it was done for baby corn.

Non-leguminous species were used as reference for natural abundance of ${ }^{15} \mathrm{~N}$ in soil. False-milkweed (Emilia sonchifolia), wandering-jew (Commelina erecta) and maize (Zea mays) were collected in the experiment area and analyzed, showing the following $\delta^{15} \mathrm{~N}$ values: $10.60 ; 9.32$ and 8.06 , respectively. The contribution of BNF was estimated using ${ }^{15} \mathrm{~N}$ or $\delta^{15} \mathrm{~N}$ abundance technique (Shearer \& Kohl, 1988), with the aid of a mass spectrometer (Finnigan MAT, model Delta Plus). The percentage contribution of $\mathrm{N}$ derived from $\mathrm{BNF}$ was calculated using the formula: $\% \mathrm{BNF}=100\left(\delta^{15} \mathrm{~N}\right.$ of control plant $-\delta^{15} \mathrm{~N}$ of fixing plant) / $\left(\delta^{15} \mathrm{~N}\right.$ of control plant $\left.-\mathrm{B}\right)$, being $\mathrm{B}$ $=-1.54$, value corresponding to the isotopic discrimination of $\delta^{15} \mathrm{~N}$ by Mucuna pruriens, according to that described by Okito et al. (2004), adopted to estimate all the other species.

Five days after the mulching species cutting, cabbage seedlings, cultivar Seicho, 32-day old, were transplanted into no-tillage system. The holes were arranged in double rows, spaced $0.4 \times 0.3 \times 0.7 \mathrm{~m}$, totalizing 64 plants per subplot and were fertilized using planting fertilizer at a rate of $6.536 \mathrm{tha}^{-1}$ of tanned bovine manure presenting the 
following chemical analysis: $15.0 ; 3.5$; $12.0 ; 14.4$ and $6.2 \mathrm{~g} \mathrm{~kg}^{-1}$, respectively of $\mathrm{N}, \mathrm{P}, \mathrm{K}, \mathrm{Ca}$ and $\mathrm{Mg}$.

The experiment design was in randomized blocks, with four replicates, arranged in split plot scheme, consisting of six treatments; plots consisted of three pre-cultivations (mulching species) and subplots with and without organic topdressing made from fermented compost $\left(0 \mathrm{t} \mathrm{ha}^{-1}\right.$ and $2.28 \mathrm{t} \mathrm{ha}^{-1}$, and the last dose equivalent to $100.0 \mathrm{~kg} \mathrm{ha}^{-1}$ $\mathrm{N})$. This compost was prepared using a mixture of wheat bran $(60 \%)$ and castor cake $(40 \%), 200 \mathrm{~L}$ of water, $2 \mathrm{~L}$ of effective microorganisms solution and $1.5 \mathrm{~kg}$ of crystal sugar; the compost was kept in plastic buckets and hermetically sealed and left to stand for 1 month for fermentation. Chemical analysis showed: $44.3 ; 4.2 ; 11.5 ; 3.3$ and $3.5 \mathrm{~g}$ $\mathrm{kg}^{-1}$, respectively $\mathrm{N}, \mathrm{P}, \mathrm{K}, \mathrm{Ca}$ and $\mathrm{Mg}$.

Cabbage harvest was performed on October 20, 2011, at 89 days after transplanting. The following agronomic traits were evaluated: whole plant fresh mass, head fresh mass, head weight. Then, subsamples of each subplot were taken. These subsamples have undergone the same steps cover crop mass has (as it was mentioned above), in order to determine dry mass and the chemical analysis of plant material.

The obtained results were submitted to statistical analysis using F test, with the aid of SAEG Program and ScottKnott test at 5\% significance level.

\section{RESULTS AND DISCUSSION}

No significant differences were observed for baby corn productivity in population densities from 100,000 to 200,000 plants ha ${ }^{-1}$ (Table 1). Average values for marketable baby corn productivity were $822.5 \mathrm{~kg} \mathrm{ha}^{-1}$. Similar values for mass of marketable fresh baby corn were found by Corrêa et al. (2014) in the same experimental area and by Jesus (2009) in the North Fluminense Region.

In relation to baby corn stigmas, the authors did not observe any significant difference between the two plant population densities (Table 1). The average productivity reached $66 \mathrm{~kg} \mathrm{ha}^{-1}$; despite of the fact that yield was not high, the high monetary value added to this by-product of baby corn harvest should be highlighted. Experimental results on stigma production were not found in literature, so that no discussion in relation to productivity reached using the adopted organic management was possible.

Productivity of shoot dry mass of green velvet was superior and was different from shoot dry mass of maize (Table 2). Productivity of shoot dry mass equivalent to $6.0 \mathrm{t} \mathrm{ha}^{-1}$ is considered an appropriate amount of straw for mulching, in no-tillage system (Darolt, 1998), in tropical conditions. On the other hand, in the Atlantic forest biome, this shoot productivity cannot be found.

Shoot dry mass of green velvet in this study was higher than the one found by Silva et al. (2011a) in similar weather conditions. However, in spite of producing greater amount of shoot phytomass, equivalent to $8.4 \mathrm{tha}^{-1}$, this leguminous plant has a low $\mathrm{C} / \mathrm{N}$ ratio, decomposing faster. Oliveira et al. (2008), analyzing different mulching decomposition, observed that $\mathrm{C} / \mathrm{N}$ ratios were lower in leguminous $C$. juncea, velvet bean (Mucuna pruriens) and gliricidia (Gliricidia sepium) comparing with sugar cane grass (bagasse) and Cameroon grass. Percentage value of dry mass remaining in grass was superior to leguminous plants, which showed low contents of remaining $\mathrm{N}$, showing faster release of this nutrient.

The authors observed that the population density of 100,000 maize plants ha ${ }^{-1}$ was higher and different from the population density of 200,000 corn plants $\mathrm{ha}^{-1}$ when analyzing mass productivities of maize shoots. In the lowest population density, productivity was similar to the value found, in similar weather conditions, by Corrêa et al. (2014) with the same cultivar. The lowest productivity reached in the highest population density allowed to verify a possible occurrence of intraspecific competition (Table 2), which did not influence in baby corn productivity, since the ears were early-harvested. For Andrade et al. (1999), this crop show low plasticity of growth when compared to other species of Poaceae family, due to its limited capacity of leaf expansion and prolificity. This botanical family produces a mass with high quality and volume (Andreola et al., 2000) and usually presents a decomposition rate inversely proportional to its $\mathrm{C} / \mathrm{N}$ ratio (Doneda, 2010), favoring the establishment of mulching.

Some studies suggest that the efficiency of grass cultivation intercropped with leguminous plants produces straw with $\mathrm{C} / \mathrm{N}$ ratio intermediate to that of the species in isolated crops, resulting in the lowest decomposition rate in relation to the phytomass when using leguminous plants exclusively, favoring the maintenance of mulching longer and synchronizing the supply stages and increased demand for $\mathrm{N}$ by crops (Corrêa et al., 2014).

The amount of N, K, Ca and $\mathrm{Mg}$ accumulated in shoot area of

Table 1. Fresh and dry mass $\left(\mathrm{kg} \mathrm{ha}^{-1}\right)$ of marketable and non-marketable husked baby corn per diameter and by deformations, dry straw mass and corn stigma dry mass, in two corn population densities. Seropédica, UFRRJ, 2011.

\begin{tabular}{|c|c|c|c|c|}
\hline \multirow{2}{*}{ Treatment } & MDC & NCBCD & MDNDef & EEC \\
\hline & \multicolumn{2}{|c|}{ Fresh mass } & \multicolumn{2}{|c|}{ Dry mass } \\
\hline M100 & $809.25 \mathrm{~A}$ & $504.78 \mathrm{~A}$ & $55.93 \mathrm{~A}$ & $67.5 \mathrm{~A}$ \\
\hline M200 & $836.12 \mathrm{~A}$ & $436.70 \mathrm{~A}$ & $67.86 \mathrm{~A}$ & $65.8 \mathrm{~A}$ \\
\hline CV (\%) & 9 & 28 & 36 & 12 \\
\hline
\end{tabular}

Averages followed by same letter in the column do not differ from each other by Scott-Knott test, $5 \%$ probability level; $\mathrm{MDC}=$ marketable husked baby corn; $\mathrm{NCBCD}=$ Non-marketable baby corn by diameter; MDNDef= Non-marketable husked baby corn, by deformations; $\mathrm{EEC}=$ Stigmas of harvested ears; $\mathrm{M} 100$ and M200= Respectively, maize grown in the density population of 100,000 and 200,000 plants $\mathrm{ha}^{-1}$. 
green velvet was higher compared to treatments with maize, which shows the high capacity of this leguminous plant for nutrient cycling (Table 2). Close values, except for $\mathrm{Ca}$, were found by Lima et al. (2010) in velvet bean, reporting average values of 196.6; $14.4 ; 100.7 ; 41.9$ and $13.9 \mathrm{~kg} \mathrm{ha}^{-1}$, for $\mathrm{N}, \mathrm{P}, \mathrm{K}, \mathrm{Ca}$ and $\mathrm{Mg}$, respectively. The amount of $\mathrm{N}, \mathrm{P}$ and $\mathrm{Mg}$ accumulated in maize shoots, in population density of 200,000 plants ha-1 was lower than that of the accumulated quantity on density of 100,000 plants ha-1 due to the lower productivity observed in the highest population density (Table 2 ). In maize population of 200,000 plants ha ${ }^{-1}$ Corrêa et al. (2014) verified values similar to the ones found in this study, except for the quantity accumulated in the shoots of $\mathrm{N}$ and $\mathrm{Ca}$.

In organic cabbage cultivation, the authors did not verify interactive effects related to the studied variation sources (pre-cultivation and dose of fermented organic compost), in relation to any analyzed variables. However, positive and independent effects were detected analyzing pre-cultivation with green velvet and topdressing using fermented organic compost on cabbage productive performance (Table 3).

In this context, pre-cultivation with green velvet provided an increase in production and, consequently, in productivity of cabbage "heads" in tha-1, when compared to pre-cultivations with different maize population densities. This increase reached about 15 and $22 \%$, corresponding to gains in productivity of heads, from 9 to $13 \mathrm{t} \mathrm{ha}^{-1}$, respectively, in relation to pre-cultivations equivalent to maize densities from 100,000 to 200,000 plants $\mathrm{ha}^{-1}$. This fact is possibly due to the benefits resulting from the greater cycling of nutrients provided by the green velvet straw, comparing to maize, mainly the cycling of nitrogen (Table 3 ).

Average cabbage head weight in the adopted organic management, both

Table 2. Mass productivity of mulching and amount of macronutrients accumulated in plant tissues. Seropédica, UFRRJ, 2011.

\begin{tabular}{|c|c|c|c|c|c|c|}
\hline \multirow{2}{*}{ Treatment } & \multirow{2}{*}{$\begin{array}{c}\text { Dry mass } \\
\left(\mathrm{t} \mathrm{ha}^{-1}\right)\end{array}$} & $\mathbf{N}$ & $\mathbf{P}$ & $\mathbf{K}$ & $\mathbf{C a}$ & Mg \\
\hline & & \multicolumn{5}{|c|}{$\left(\mathrm{kg} \mathrm{ha}^{-1}\right)$} \\
\hline M100 & $4.9 \mathrm{~B}$ & $61.3 \mathrm{~B}$ & $16.4 \mathrm{~A}$ & $65.1 \mathrm{~B}$ & $9.65 \mathrm{~B}$ & $11.0 \mathrm{~B}$ \\
\hline M200 & $3.3 \mathrm{C}$ & $43.5 \mathrm{C}$ & $12.1 \mathrm{~B}$ & $52.1 \mathrm{~B}$ & $6.42 \mathrm{~B}$ & $7.7 \mathrm{C}$ \\
\hline MV100 & $8.4 \mathrm{~A}$ & $184.6 \mathrm{~A}$ & $11.9 \mathrm{~B}$ & $91.0 \mathrm{~A}$ & $145.40 \mathrm{~A}$ & $20.0 \mathrm{~A}$ \\
\hline $\mathrm{CV}(\%)$ & 16 & 20 & 26 & 20 & 20 & 28 \\
\hline
\end{tabular}

Averages followed by same letters in the column do not differ from each other by Scott-Knott test, $5 \%$ probability; M100 and M200= Maize grown in the population density of 100,000 and 200,000 plants ha $^{-1}$, respectively; MV100 $=$ Green velvet cultivated in the population density of 200,000 plants ha-1.

Table 3. Fresh mass of the whole plant, cabbage "head" average weight and N content of cabbage, cultivated in no-tillage system, on mulching mass with and without organic fertilization. Seropédica, UFRRJ, 2011.

\begin{tabular}{|c|c|c|c|c|}
\hline $\begin{array}{l}\text { Kind of } \\
\text { straw }\end{array}$ & $\begin{array}{l}\text { Whole plant } \\
\text { mass }\left(t \text { ha }^{-1}\right)\end{array}$ & $\begin{array}{c}\text { Head mass } \\
\text { (kg per plant) }\end{array}$ & $\begin{array}{l}\text { Head productivity } \\
\qquad\left(\mathrm{t} \mathrm{ha}^{-1}\right)\end{array}$ & $\mathbf{N}$ content \\
\hline M100 & $78.93 \mathrm{~B}$ & $1.03 \mathrm{~B}$ & $51.46 \mathrm{~B}$ & $22.9 \mathrm{~B}$ \\
\hline M200 & $72.44 \mathrm{~B}$ & $0.94 \mathrm{~B}$ & $47.14 \mathrm{~B}$ & $21.8 \mathrm{~B}$ \\
\hline MV100 & $87.29 \mathrm{~A}$ & $1.21 \mathrm{~A}$ & $60.77 \mathrm{~A}$ & $28.2 \mathrm{~A}$ \\
\hline \multicolumn{5}{|c|}{ Organic compost } \\
\hline $0 \mathrm{~N}$ & $72.05 \mathrm{~B}$ & $0.92 \mathrm{~B}$ & $46.22 \mathrm{~B}$ & $22.5 \mathrm{~B}$ \\
\hline $100 \mathrm{~N}$ & $87.4 \mathrm{~A}$ & $1.20 \mathrm{~A}$ & $60.44 \mathrm{~A}$ & $26.0 \mathrm{~A}$ \\
\hline
\end{tabular}

Averages followed by same letters in the column do not differ from each other by Scott-Knott test, 5\% probability; M100 and M200= Maize grown in the population density of 100,000 and 200,000 plants $\mathrm{ha}^{-1}$, respectively; MV100 $=$ Green velvet cultivated in the population density of 200,000 plants ha- ${ }^{-1} ; 0 \mathrm{~N}=0.0 \mathrm{~kg} \mathrm{ha}^{-1} \mathrm{~N} ; 100 \mathrm{~N}=100.0 \mathrm{~kg} \mathrm{ha}^{-1} \mathrm{~N}$. in pre-cultivation with green velvet and in the presence of mulching, was similar to the observed by Moreira et al. (2011). Analyzing cabbage production in relation to synthetic-N fertilizer, Moreira et al. (2011) obtained the maximum estimated value of $1.13 \mathrm{~kg}$ of head fresh mass, applying $278 \mathrm{~kg} \mathrm{~N} \mathrm{ha}^{-1}$.

Values of cabbage productivity, using green velvet straw and maize straw, reached levels similar to the ones found by Vargas et al. (2011), under conventional cultivation with C. juncea and C. ensiformis straw, and using nitrogen fertilization with $75 \mathrm{~kg}$ of $\mathrm{N}$ ha-1, yield was between 47.0 to 58.0 $\mathrm{t} \mathrm{ha}^{-1}$. Oliveira et al. (2003) reached productivity of $34.7 \mathrm{t} \mathrm{ha}^{-1}$, under organic cultivation with $C$. juncea straw, in population density of 27,778 plants $\mathrm{ha}^{-1}$. Under the same weather conditions, Santos (2009) found productivity ranging from 62 to $74 \mathrm{t} \mathrm{ha}^{-1}$, growing cabbage with $C$. juncea straw, under mono and intercropping system with either sunflower or sorghum, under the same edaphoclimatic conditions.

Higher accumulations of N, P and $\mathrm{Mg}$ in cabbage shoots were provided by pre-cultivation with green velvet, differing statistically from the other treatments (Figure 1). These values are close to the ones found by Pereira (2007), evaluating nutrient accumulation in cabbage mass, under no-tillage on $C$. juncea straw; Pereira (2007) found 99.6; $11.6 ; 131.8 ; 16.7 ; 6.0 \mathrm{~kg} \mathrm{ha}^{-1}$ of N, P, K, $\mathrm{Ca}$ and $\mathrm{Mg}$, respectively.

In relation to $\mathrm{BNF}$ through the use of green velvet, the amount of $\mathrm{N}$ from the atmosphere, estimated by natural abundance of ${ }^{15} \mathrm{~N}$ technique, was $62 \%$ similar to the value found by Silva et al. (2011a), which is the accumulated amount of $114.32 \mathrm{~kg} \mathrm{ha}^{-1}$ of $\mathrm{N}$ in the shoots. Considering the equivalence, disregarding soil $\mathrm{N}$ recovery efficiency by the cabbage from decomposition process of green velvet straw, this value corresponds to an application of $254 \mathrm{~kg}$ $\mathrm{ha}^{-1}$ of a concentrated synthetic fertilizer (urea). Considering the $\mathrm{N}$ fertilization recommended by Filgueira (2008), the amount of $\mathrm{N}$ derived from accumulated BNF only in green velvet shoots, is a value close to what is recommended for this crop. In this context, considering 
organic management, pre-cultivation with green velvet shows potential to provide significant amount of $\mathrm{N}$ to reach productivity levels similar to the ones obtained under conventional management.

Evaluating $\mathrm{N}$ contents in cabbage heads (Table 3), the authors observed that in green velvet straw cultivation $\mathrm{N}$ content was higher, differing significantly from the other treatments. This is due to the fact that this species performs biological fixation with atmospheric $\mathrm{N}_{2}$ fixing bacteria.

Using the results, the authors concluded that cabbage which had been organically cultivated, under notillage system using green velvet, in the absence of topdressing application, with fermented organic compost, did not show any mass productivity decrease when compared with organic fertilized treatment (Table 3). These results show the contribution of BNF through the use of green velvet, after straw decomposition, as an effective source

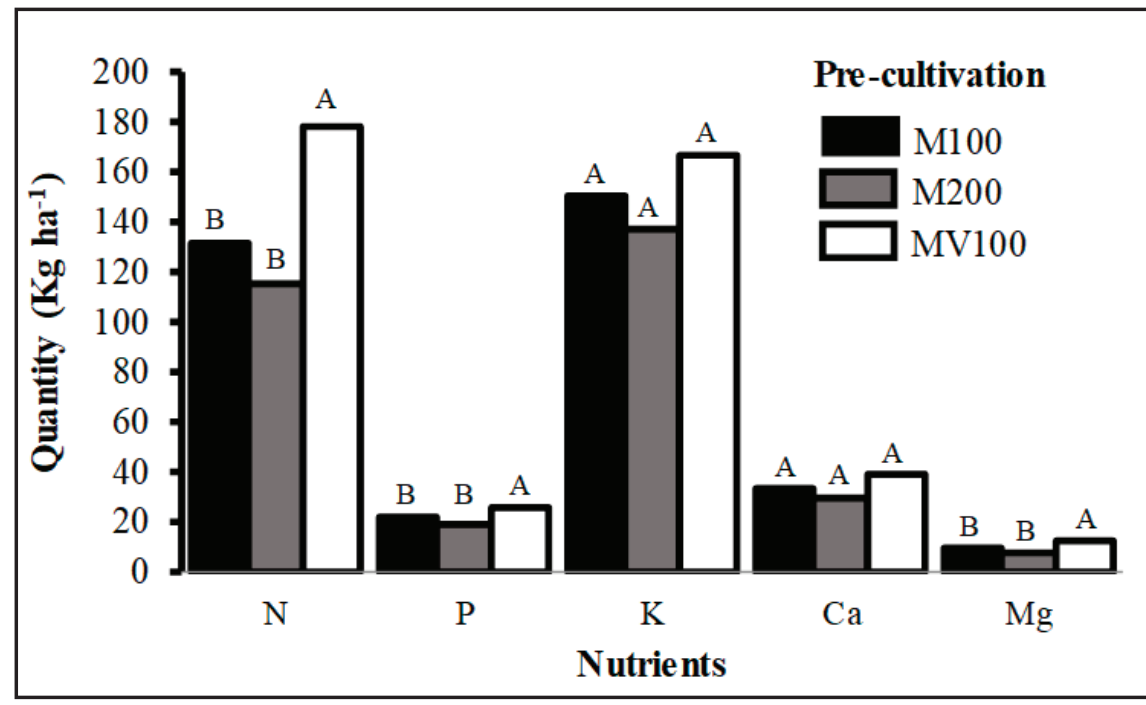

Figure 1. Accumulated amount of nutrients in shoots of cabbage, cultivated on the mulching straw; ${ }^{1}$ Bars with the same letters do not differ among themselves by Scott-Knott test, 5\% probability; M100 and M200= Maize grown in the population density of 100,000 and 200,000 plants $^{-1}$, respectively; MV100 $=$ Green velvet cultivated in the population density of 200,000 plants ha-1. Seropédica, UFRRJ, 2011.

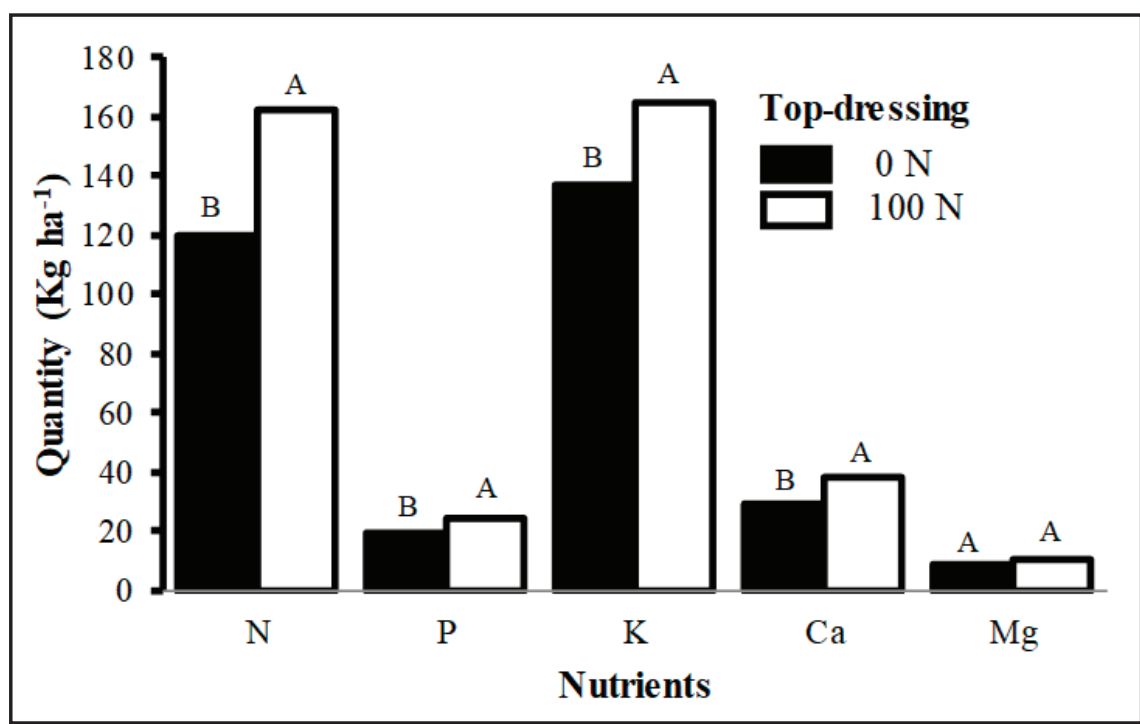

Figure 2. Amount of nutrients accumulated in shoot of cabbage using topdressing with organic compost; ${ }^{1}$ Bars with the same letters do not differ among themselves by Scott-Knott test, $5 \%$ probability; $0 \mathrm{~N}=0.0 \mathrm{~kg} \mathrm{ha}^{-1} \mathrm{~N} ; 100 \mathrm{~N}=100.0 \mathrm{~kg} \mathrm{ha}^{-1} \mathrm{~N}$. Seropédica, UFRRJ, 2011. of $\mathrm{N}$ supply for the crop. Thus, organic topdressing can be replaced by precultivation with this leguminous plant, showing advantage of soil protection and, also monetary-cost benefits. Thus, this system can be an alternative for organic production systems, in which the use of synthetic $\mathrm{N}$ fertilizers is not allowed, as well as in conventional production systems.

In this context, Pereira (2007) suggests replace supplementary organic fertilization by pre-cultivation with C. juncea, since the productivity of cabbage grown on the straw of this leguminous plant, without topdressing application, did not differ from the productivity of cabbage with poultry litter, $200 \mathrm{~kg} \mathrm{ha}^{-1} \mathrm{~N}$.

In relation to the amount of nutrients accumulated in cabbage shoots, the authors observed that the topdressing with fermented organic compost resulted in an increase of N, P, K and Ca (Figure 2) when compared to the absence of this organic fertilization. Similarly, Oliveira et al. (2003) reported that supplementary topdressing with poultry litter, in cabbage cultivation, provided an increase in nutrient accumulation in the shoot area.

The authors concluded that population density of 100,000 maize plants ha ${ }^{-1}$ provided the same productivity of baby corn fresh mass and maize stigma dry mass, as density of 200,000 maize plants ha ${ }^{-1}$. However, in the lower population density, shoot productivity is higher than the productivity found in the higher density, making it the best alternative, considering productivity indexes, seed economy and ease of crop management.

Pre-cultivations with maize and green velvet resulted in high productivity of dry shoot phytomass, which shows that a strategy favoring the use of these species can provide the production of straw produced in situ aiming to cabbage minimal cultivation under organic production systems.

Productivity of cabbage on green velvet straw was higher than the productivity of cabbage grown on maize straw, considering that topdressing with the compost did not result in an additional gain in relation to this 
vegetable yield, this system showed to be unnecessary. Even cabbage being cultivated on the maize straw showed satisfactory productivity, above national average, and increased in the presence of topdressing fertilization with the organic compost "bokashi" obtained from wheat fermentation and cake.

\section{ACKNOWLEDGEMENTS}

The authors thank to Coordination of Improvement of Higher Education Personnel (CAPES), Universidade Federal Rural do Rio de Janeiro (UFRRJ), Embrapa Agrobiologia, Foundation for Research Support of Rio de Janeiro (FAPERJ) and The National Council for Scientific and Technological Development $\mathrm{CNPq}$ ) for the financial support for the experimental study.

\section{REFERENCES}

ANDRADE, FH; VEGA, C; UHART, S; CIRILO, A; CANTARERO, M; VALENTINUZ, O. 1999. Kernel number determination in maize. Crop Science 39: 453-459.

ANDREOLA, F; COSTA, LM; OLSZEVSKI, N; JUCKSCH, I. 2000. A cobertura vegetal de inverno e a adubação orgânica e, ou, mineral influenciando a sucessão feijão/milho. Revista Brasileira de Ciência do Solo 24: 867-874.

AQUINO, LA; PUIATTI, M; PEREIRA, PRG; PEREIRA, FHF; CASTRO, MRS; LADEIRA, R. 2005. Características produtivas do repolho em função de espaçamentos e doses de nitrogênio. Horticultura Brasileira 23: 266270.

BARBOSA GR. 2009. Cultivares de milho a diferentes doses de zinco para produção de minimilho em Vitória da Conquista-BA. Vitória da Conquista: UESB, 54p. (MSc. thesis).

CORRÊA, AL; ABBOUD, ACS; GUERRA, JGM; AGUIAR, LA; RIBEIRO, RLD. 2014. Adubação verde com crotalária consorciada ao minimilho antecedendo a couve-folha sob manejo orgânico. Ceres 61: 956-963.

DAROLT, MR. 1998. Princípios para implantação e manutenção de sistemas. In: Plantio direto: pequena propriedade sustentável. Londrina: IAPAR. p.16-45.
DONEDA, A. 2010. Plantas de cobertura de solo consorciadas e em cultivo solteiro: decomposição e fornecimento de nitrogênio ao milho. Santa Maria: UFSM. 79p (MSc. thesis).

FILGUEIRA, FAR. 2008. Novo manual de olericultura: Agrotecnologia moderna na produção e comercialização de hortaliças. $3^{\mathrm{a}}$ ed. Viçosa: UFV. 412p.

JESUS, VP. 2009. Produção de minimilho (Zea mays l.) em diferentes sistemas de manejo. Campos dos Goytacazes: UENF. 59p (MSc. thesis).

LI, FL; YU, L. 2009. Flavonoids extraction from maize silk and its function on blood sugar control. China Food Additives 94: 121-124.

LIMA, JD; SAKAI, RK; ALDRIGHI, M; SAKAI, M. 2010. Arranjo espacial, densidade e época de semeadura no acúmulo de matéria seca e nutrientes de três adubos verdes. Pesquisa Agropecuária Tropical 40: 531-540.

MATA, MG; GUERRA, JGM; PINHEIRO, EFM; CEDDIA, MC. 2016. Análise espaçotemporal dos atributos químicos do solo de um módulo de pesquisa em produção orgânica. In: AMARAL SOBRINHO, NMB; CHAGAS, CI; ZONTA, E. (org). Impactos ambientais provenientes da produção agrícola: experiências argentinas e brasileiras. 1. ed. Livre Expressão. p.165-197.

MOREIRA, MA; VIDIGAL, SM; SEDIYAMA, MAN; SANTOS, MR. 2011. Crescimento e produção de repolho em função de doses de nitrogênio. Horticultura Brasileira 29: 117-121.

OKITO, A; ALVES, BRJ; URQUIAGA, S; BODDEY, RM. 2004. Isotopic fractionation during N2 fixation by four tropical legumes. Soil Biology \& Biochemistry 36: 1179-190.

OLIVEIRA, FL; GUERRA, JGM; ALMEIDA, DL; RIBEIRO, RLD; SILVA, ED; SILVA, VV; ESPINDOLA, JAA. 2008. Desempenho de taro em função de doses de cama de aviário, sob sistema orgânico de produção. Horticultura Brasileira 26: 149-153.

OLIVEIRA, EAG. 2015. Formulações tipo "bokashi" como fertilizantes orgânicos no cultivo de hortaliças. Seropédica: UFRRJ. 79p. (Ph.D. thesis)

OLIVEIRA, FL; GUERRA, JGM; ALMEIDA, DL; RIBEIRO, RLD; ESPINDOLA, JAA; RICCI, MSF; CEDDIA, MB. 2008. Avaliação de coberturas mortas em cultura de alface sob manejo orgânico. Horticultura Brasileira 26: 216-220.

OLIVEIRA, FL; RIBAS, RGT; JUNQUEIRA, RM; PADOVAN, MP; GUERRA, JGM; ALMEIDA, DL; RIBEIRO, RLD. 2003. Uso do pré-cultivo de Crotalaria junceae de doses crescentes de "cama" de aviário na produção do repolho sob manejo orgânico. Agronomia
37: 60-66.

PEREIRA, AJ. 2007. Caracterização agronômica de espécies de Crotalaria L. em diferentes condições edafoclimáticas e contribuição da adubação verde com Crotalaria juncea no cultivo orgânico de brássicas em sistema de plantio direto. Seropédica: UFRRJ. 72p (Ph.D. thesis).

PEREIRA FILHO, IA; CRUZ, JC. 2001. Manejo cultural do minimilho. Revista Brasileira Agropecuária 3: 41-43.

SANTOS, CAB. 2009. Consórcios de espécies de cobertura de solo para adubação verde, antecedendo ao cultivo milho e repolho sob manejo orgânico. Seropédica: UFRRJ. 80p (M.Sc. thesis).

SEDIYAMA, MAN; SANTOS, IC; LIMA, PC. 2014. Cultivo de hortaliças no sistema orgânico. Revista Ceres 61: 829-837,

SHEARER, G; KOHL, DH. 1988. Natural $15 \mathrm{~N}$ - abundance a method of estiming the contribution of biological fixed nitrogen to $\mathrm{N}_{2}$ - fixing systems: Potential for non-legumes. Plant and Soil 110: 317-327.

SILVA, AGB; GUERRA, JGM; GONÇALVES JUNIOR, M; COSTA, JR; ESPÍNDOLA, JAA; ARAÚJO, ES. 2011a. Desempenho agronômico de mucuna verde em diferentes arranjos espaciais. Pesquisa Agropecuária Brasileira 46: 603-608.

SILVA, EE; POLLI, H; GUERRA, JGM; AGUIAR-MENEZES, EL; RESENDE, ALS; OLIVEIRA, FL; RIBEIRO, RLD. $2011 \mathrm{~b}$. Sucessão entre cultivos orgânicos de milho e couve consorciados com leguminosas em plantio direto. Horticultura Brasileira 29: 57-62.

SILVA, KS; SANTOS, ECM; BENETT, CGS; LARANJEIRA, LT; EBERHARDT NETO, E; COSTA, E. 2012. Produtividade e desenvolvimento de cultivares de repolho em função de doses de boro. Horticultura Brasileira 30: 520-525.

SILVA, VV. 2002. Efeito do pré-cultivo de adubos verdes na produção orgânica de brócolos (Brassica oleraceae var. Itálica) em sistema de plantio direto. Seropédica: UFRRJ. 80p (M.Sc. thesis).

SIQUEIRA, AP; SIQUEIRA, MFB. 2013. Bokashi: adubo orgânico fermentado. Niterói: Programa Rio Rural, 16p. (Manual Técnico, 40).

VARGAS, TO; DINIZ, ER; SANTOS, RHS; LIMA, CTA; URQUIAGA, S; CECON, PR. 2011. Influência da biomassa de leguminosas sobre a produção de repolho em dois cultivos consecutivos. Horticultura Brasileira 29: 562-568. 